\title{
A REVIEW OF THE EVIDENCE FOR EXTINCTION CHRONOLOGIES FOR FIVE SPECIES OF UPPER PLEISTOCENE MEGAFAUNA IN SIBERIA
}

\author{
Lyobov A Orlova ${ }^{1} \cdot$ Yaroslav V Kuzmin $^{2} \cdot$ Vyacheslav N Dementiev ${ }^{1,3}$
}

ABSTRACT. A review of the radiocarbon chronology of some late Upper Pleistocene mammals from Siberia is presented. Previously published data has been supplemented by new ${ }^{14} \mathrm{C}$ dates for 5 species (woolly mammoth, woolly rhinoceros, bison, horse, and muskox) to reconstruct chronological extinction patterns. The final extinction of woolly rhinoceros and bison in Siberia can be dated to approximately 11,000-9700 BP, but some megafaunal species (woolly mammoth, horse, and muskox) survived into the Late Holocene, about 3700-2200 BP.

\section{INTRODUCTION}

Determining the extinction patterns of Upper Pleistocene megafauna using radiocarbon dating was first conducted in Siberia in the early 1960s (Heintz and Garutt 1964, 1965; Heintz 1966). Since that time, the number of ${ }^{14} \mathrm{C}$ dates obtained directly from megafaunal species has significantly increased and now constitutes several hundred values. The majority of dates were obtained for such species as woolly mammoth (Mammuthus primigenius Blum.), woolly rhinoceros (Coelodonta antiquitatis Blum.), Pleistocene bison (Bison priscus Boj.), Pleistocene-type horse (Equus caballus L.), and muskox (Ovibos moschatus Zimm.). These data provide a basis for establishing the timing of the megafauna's final extinction in Siberia and the Russian Far East, and in the adjacent territories of Kazakhstan and Northeastern China. The aim of this paper is to present an extended data set which enhances our understanding of extinction patterns for the species and compare the data set to previous summaries (cf. Stuart 1991; Sulerzhitsky 1997; Vasil'chuk et al. 1997).

\section{MATERIAL AND METHODS}

We have compiled data from published sources (mainly from Sulerzhitsky 1997; Sulerzhitsky and Romanenko 1999; Vasil'chuk et al. 1997; Orlova et al. 2000; Stuart et al. 2002; MacPhee et al. 2002; Schirrmeister et al. 2002; Kuzmin et al. 2003), with new ${ }^{14} \mathrm{C}$ dates produced at the Institute of Geology, Siberian Branch of the Russian Academy of Sciences, Novosibirsk (Lab code SOAN). The number of ${ }^{14} \mathrm{C}$ dates known for extinct megafaunal species in Siberia is skewed towards woolly mammoth, with about $530{ }^{14} \mathrm{C}$ values from 230 localities. Of these, we have concentrated on only the "youngest" dates, less than about $12,000 \mathrm{BP}$, because they are directly related to the issue of extinction (Table 1; Figure 1). Other species have far fewer ${ }^{14} \mathrm{C}$ determinations; for example, there are 59 dates on bison from 51 localities, 55 dates on horse from 33 localities, 41 dates on woolly rhinoceros from 35 localities, and 29 dates on muskox from 19 localities (Tables 2-5; Figures 2-3).

The dating of megafaunal remains was conducted mainly using bone collagen as the source of carbon. Dates produced in Russian laboratories, located in Moscow, Novosibirsk, and St Petersburg, comprise $85 \%$ of the total ${ }^{14} \mathrm{C}$ values discussed in this paper. The main technique of collagen extraction for bone dating in Russian laboratories since the late 1960s is the dissolution of the mineral part of the bone in weak hydrochloric acid (HCl) (Arslanov and Svezhentsev 1993; Sulerzhitsky 1997;

\footnotetext{
${ }^{1}$ Institute of Geology, Siberian Branch of the Russian Academy of Sciences, Koptuyg Ave. 3, Novosibirsk 630090, Russia. Email: orlova@uiggm.nsc.ru.

${ }^{2}$ Pacific Institute of Geography, Far Eastern Branch of the Russian Academy of Sciences, Radio St. 7, Vladivostok 690041, Russia. Email: ykuzmin@tig.dvo.ru.

${ }^{3}$ Email: dementev@uiggm.nsc.ru.
}

(C) 2004 by the Arizona Board of Regents on behalf of the University of Arizona Proceedings of the 18th International Radiocarbon Conference, edited by N Beavan Athfield and R J Sparks RADIOCARBON, Vol 46, Nr 1, 2004, p 301-314 
see detailed description in Vasil'ev et al. 2002:505-7). Slow dissolution of the mineral part of whole pieces of bone in diluted $\mathrm{HCl}$ makes it possible to extract non-contaminated collagen and to see the degree of preservation of the initial fiber-like internal collagen structure after demineralization. The reliability of the slow dissolution technique for collagen extraction is also supported by good agreement of results of parallel dating on the same pieces of bone conducted in Russian, US, and European laboratories (Vartanyan et al. 1995; Vasil'chuk et al. 2000; Kuzmin et al. 2001; MacPhee et al. 2002).

The date of final extinction was estimated using the latest ${ }^{14} \mathrm{C}$ date available for a particular species, an approach employed in similar studies (cf. Stuart et al. 2002; MacPhee et al. 2002; Guthrie 2003). The extent of the species' habitats (i.e. the natural home or environment of an organism) were assumed by the geographic distribution of their fossil remains (cf. Kuzmin et al. 2003:223-5) and are listed in Tables $1-5$ by latitude and longitude, given as decimal values (e.g. $70.50 \mathrm{~N}$ means $70^{\circ} 30^{\prime}$ northern latitude), as per the US Defense Mapping Agency Operational Navigation Charts (scale of 1:1,000,000). GIS ArcView 3.2 software was used for map generation.

\section{RESULTS AND DISCUSSION}

\section{Woolly Mammoth}

As previously noted, we selected 56 of the latest ${ }^{14} \mathrm{C}$ dates from 26 localities covering the Late Glacial and the Holocene, about 12,000-3700 BP (Table 1; Figure 1). As for earlier times, about $50,000-12,000 \mathrm{BP}$, it is clear that the woolly mammoth habitat extended through all of Northern Asia-Siberia, the Russian Far East, northeastern China, and northern Kazakhstan (cf. Sulerzhitsky 1997; Kuzmin et al. 2003). The distribution pattern appears to have changed significantly, by about 12,000-10,000 BP (Figure 1). The mammoth habitat was substantially reduced in size and located mainly in arctic Siberia, including the lower part of the Indigirka River basin, the Taymyr, Yamal, and Gydan peninsulas, the Severnaya Zemlya archipelago, and Wrangel Island. The Taymyr Peninsula mammoths have the youngest ${ }^{14} \mathrm{C}$ dates in continental Siberia of about $9800-9700$ BP. New ${ }^{14} \mathrm{C}$ dates obtained in 2000-2002 also reveal several mammoth sites in the temperate belt of Siberia dated to approximately 11,980-10,210 BP, including the central and southern West Siberian Plain (Volchya Griva, Sosva River, and Lugovskoe) and the Upper Yenisei River basin (Konzhul) (Table 1; Figure 1). In our opinion, these localities represent the "patchy" nature of the mammoth habitat in Siberia after about 12,000 BP, with few isolated "pockets" outside of the High Arctic. Finally, in the Middle Holocene, about 7700-3700 BP, smaller mammoths (a subspecies, M. primigenius vrangeliensis; Averyanov et al. 1995) existed only on Wrangel Island.

These data suggest that the final extinction of woolly mammoth in Siberia and elsewhere in the Northern Hemisphere occurred at about 9700 BP in the continental part (Taymyr Peninsula), and at about $3700 \mathrm{BP}$ in the insular part (Wrangel Island). Our extended data set presented here indicates mammoth survival in temperate Siberia after shrinking and fragmentation of its habitat at about $12,500-12,000 \mathrm{BP}$. Based on this, it is possible to assume that even after approximately 12,000 BP some mammoth populations survived outside of arctic regions in a few places in continental Eurasia (Western Siberia, north Russian Plain in Eastern Europe) until the beginning of the Holocene (Stuart et al. 2002; Lõugas et al. 2002).

\section{Woolly Rhinoceros}

The distribution of woolly rhinoceros ${ }^{14} \mathrm{C}$ dates indicates its habitat covered Northeastern Siberia and the southern parts of Western and Eastern Siberia (Figure 2) in the late Upper Pleistocene, from 


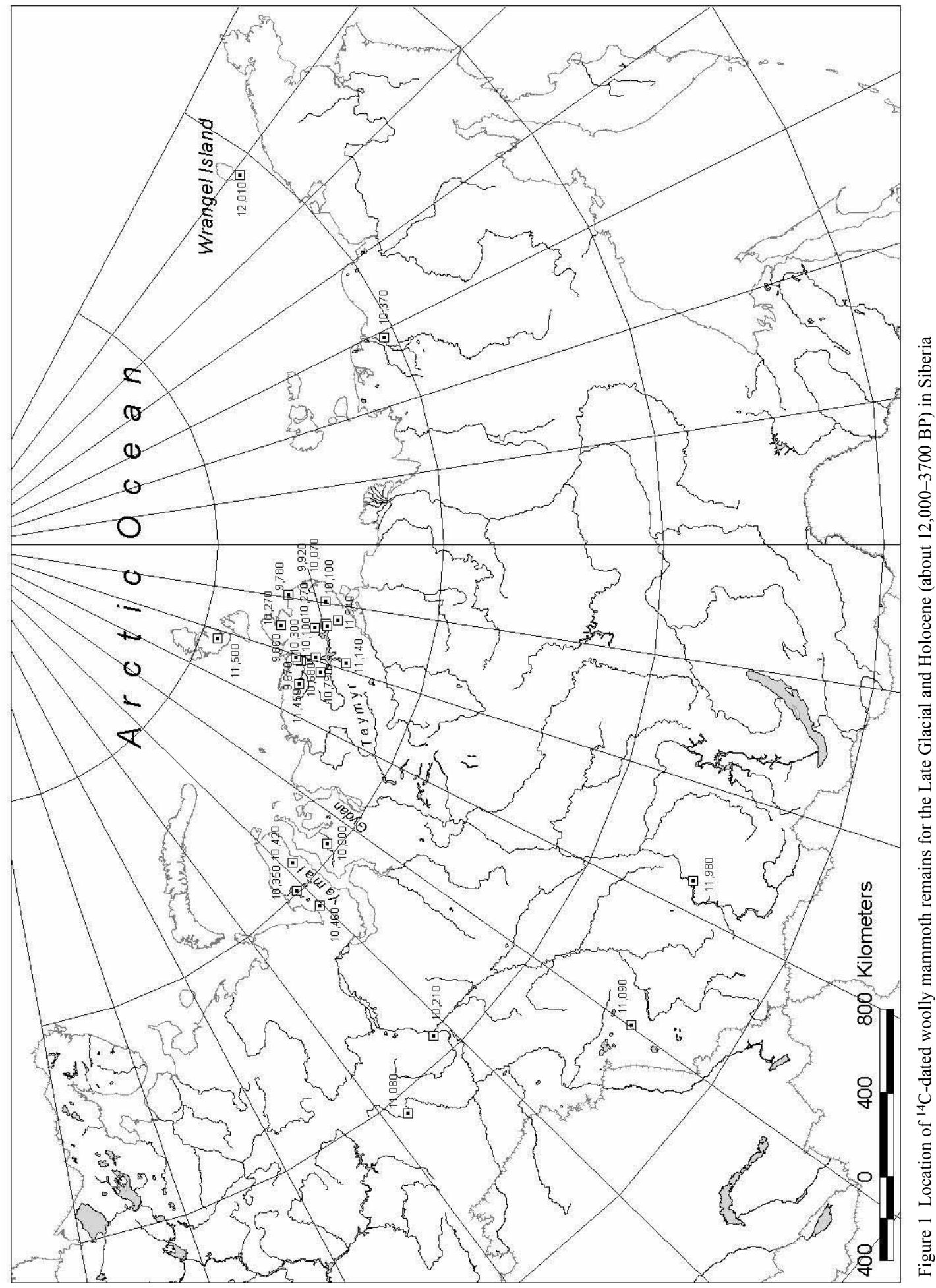




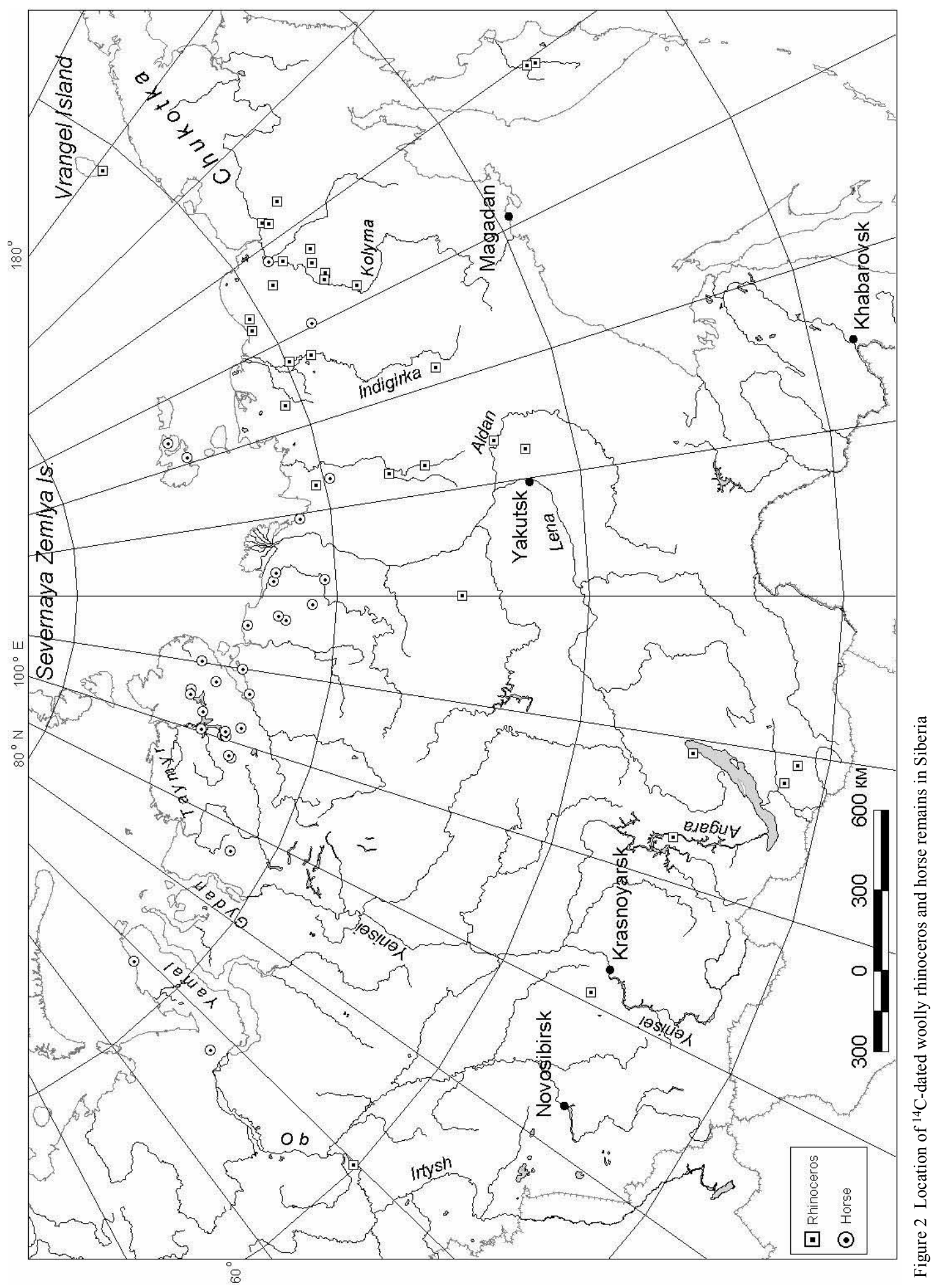


about 49,000 BP, as well as the Russian Far East (without direct ${ }^{14} \mathrm{C}$ dates). In the northern parts of Western and Eastern Siberia (Putorana Plateau, and the Taymyr, Gydan, and Yamal peninsulas), no remains of woolly rhinoceros have been recovered, perhaps indicating that these areas were not part of its natural habitat as was earlier assumed by R-D Kahlke (1998). The latest ${ }^{14} \mathrm{C}$ dates for the species are from the Bolshoi Khomus-Yuriakh River, Yakutia (about 15,130 BP); Yukagir Plateau, Northeastern Siberia (about 14,260 BP); Zlatoustovka, Ashkadar River, southern Trans-Urals (about 12,330 BP); and Lugovskoe, central Western Siberia (about 10,770 BP) (Table 2). It is worthwhile highlighting that the ${ }^{14} \mathrm{C}$ dates from temperate Siberia (Zlatoustovka and Lugovskoe) are significantly younger than those from arctic regions.

With the new ${ }^{14} \mathrm{C}$ date from the Lugovskoe locality, the final extinction of woolly rhinoceros could be as late as the end of the Late Glacial (about 10,800 BP), rather than as suggested at approximately 14,000-12,000 BP by Vereshchagin and Baryshnikov (1984:497-9). Further study is thus necessary on this ${ }^{14} \mathrm{C}$ chronology in Siberia to confirm/reject the 10,800 BP age for its final extinction, especially in the areas with the youngest dates such as Western Siberia and the Trans-Urals.

\section{Bison}

The bison habitat in the late Upper Pleistocene extended throughout all of the Siberian and the Russian Far Eastern territory (Figure 3). In most of Siberia, bison were extinct by approximately 15,000-11,600 BP (Table 3). Bison persisted only in a few places into the Holocene. The latest bison ${ }^{14} \mathrm{C}$ date, about $8860 \mathrm{BP}$, comes from the Popigai River basin, northern Eastern Siberia, next to the Taymyr Peninsula (MacPhee et al. 2002). At the Sushikha locality, southern West Siberian Plain, the tentative age of bison occupation, about $9320 \mathrm{BP}$, requires further study due to only a single ${ }^{14} \mathrm{C}$ value obtained so far from this locality and the fragmentary nature of the fossils. Similar aged bison remains are known from the Ust-Belaya site (layers 3-4) at the Angara River headwaters, southern Eastern Siberia, with an associated ${ }^{14} \mathrm{C}$ bone date of $8960 \pm 60$ BP (GIN-96) (Kuzmin and Orlova 1998:18; MacPhee et al. 2002:1033). Nevertheless, no details are available about the association of ${ }^{14} \mathrm{C}$-dated bone and the bison remains, and this value should, therefore, be treated with caution. The existence of Bison priscus in southern Siberia in the Early Holocene is still in doubt and requires additional study.

\section{Horse}

Although there are many Upper Pleistocene findings of horse fossils in Siberia (cf. Vangengeim 1977; Vereshchagin and Baryshnikov 1984; Markova et al. 1995), ${ }^{14} \mathrm{C}$-dated localities are known mostly from the northern parts of Western, Eastern, and Northeastern Siberia (Figure 2). Most of the youngest dates correspond to the Late Glacial and the Pleistocene-Holocene boundary, about 15,300-9010 BP (Table 4). However, in the Holocene, small populations of horse existed on the Laptev Sea coast and the Taymyr Peninsula. At the Bykovsky Peninsula locality, on the Laptev Sea coast near the modern town of Tiksi, a ${ }^{14} \mathrm{C}$ date of $4610 \pm 40 \mathrm{BP}$ was obtained; and on the Bolshoi Lyakhovsky Island (Novosibirsk archipelago), the value of $2200 \pm 50$ BP was generated (Kuznetsova et al. 2001). On the Taymyr Peninsula, ${ }^{14} \mathrm{C}$ dates of $3250 \pm 60$ BP (Agapa River basin) and $2150 \pm 200$ BP (Bolshaya Balakhnya River basin) have been previously reported (MacPhee et al. 2002). These dates support that horse existed in arctic Siberia into the Late Holocene.

The data shows an extinction pattern which illustrates a disappearance of horse in Siberia at about 11,700-9000 BP, but an apparent reappearance in arctic Siberia at about 4600 BP, and finally becoming extinct throughout the region at about $2200 \mathrm{BP}$. The cause of the hiatus in the existence of horse in this region between approximately 9000 and 4600 BP is not clear (MacPhee et al. 2002: 1034-40). 


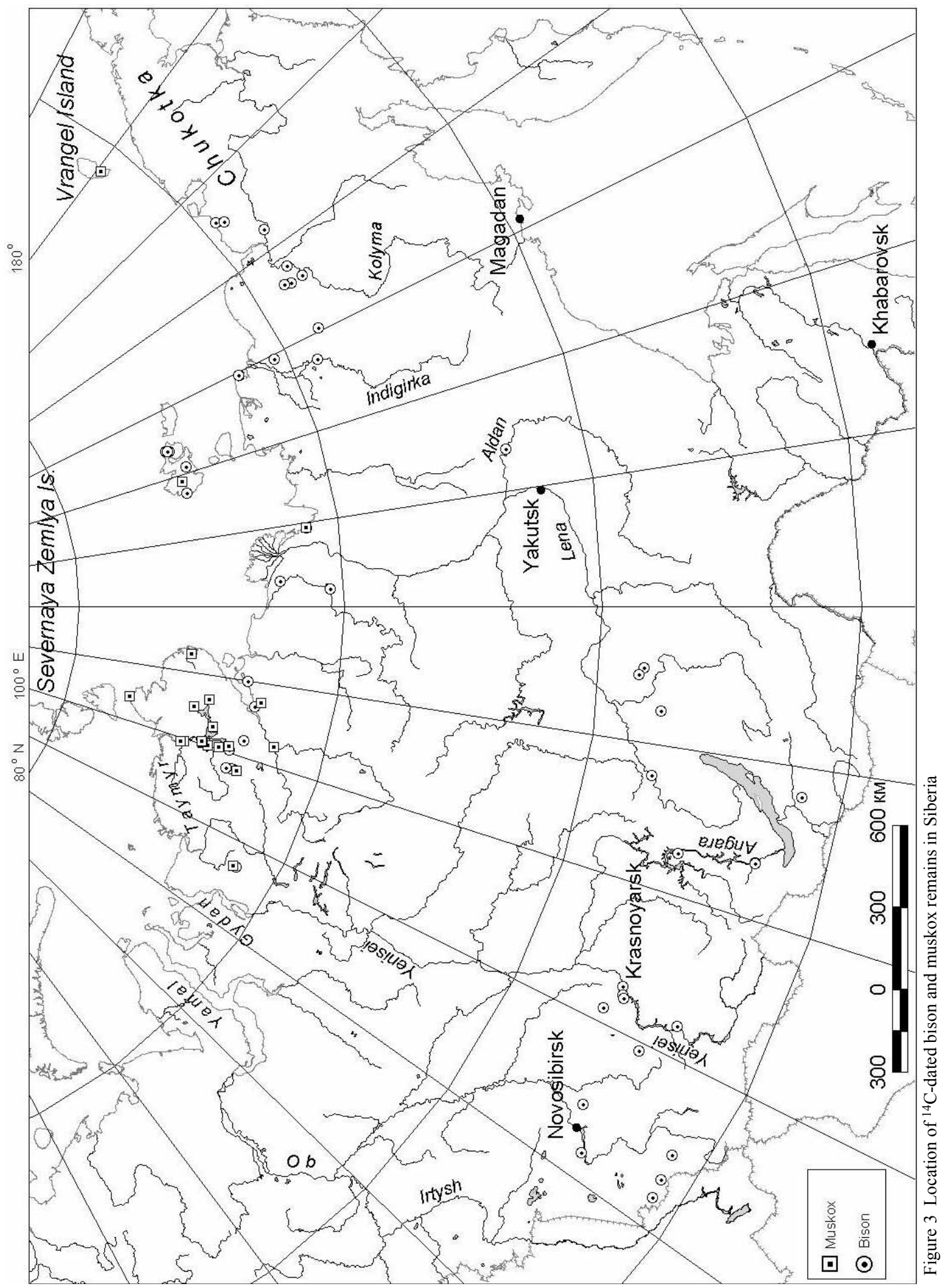




\section{Muskox}

Fossils of muskox are rare in Siberia and are concentrated mainly in what are today arctic regions, from where ${ }^{14} \mathrm{C}$-dated remains are found (Figure 3). The highest concentration of dates is on the Taymyr Peninsula (MacPhee et al. 2002). The majority of the latest ${ }^{14} \mathrm{C}$ dates run on muskox belong to the Late Glacial, about 12,150-10,750 BP (Table 5). However, in the Late Holocene, muskox reappeared on the Laptev Sea coast and the Taymyr Peninsula at about 3200-2900 BP, and continued to exist until about 2700 BP (Sulerzhitsky and Romanenko 1999; Kuznetsova et al. 2001). This pattern is similar to the Holocene dynamics of horse in the same region, with a significant hiatus on the Taymyr Peninsula from approximately 12,150 BP to 2900 BP (MacPhee et al. 2002:1030-3).

\section{CONCLUSION}

From the data presented, we conclude that the major extinction of the Pleistocene fauna representatives in continental Siberia can be dated to approximately 11,000-9700 BP. In the insular territories, (for example, Wrangel Island), a few species such as woolly mammoth survived until the Late Holocene, about 3700 BP. Some species, such as horse and muskox, reappeared in continental arctic Siberia in the Holocene. Thus, the dynamics of the megafaunal species was quite complex and "mosaic-like" in their geographic and chronological patterns, with hiatuses in the ${ }^{14} \mathrm{C}$ age distribution for some species, possibly reflecting the re-colonization after a long absence.

Our data also allows us to assume that the central and southern parts of the West Siberian Plain contained several apparent refuge areas for Pleistocene species, including mammoth (until about $10,200 \mathrm{BP}$ ), woolly rhinoceros (until about 10,800 BP), and possibly bison (until about $9000 \mathrm{BP}$ ). The existence of isolated megafaunal populations beyond the Arctic after about 12,000 BP is at odds with current Pleistocene extinction models, but will provide an interesting challenge for future research.

\section{ACKNOWLEDGEMENTS}

We are grateful to colleagues who helped us to collect original data which were used in this study, including Drs Leopold D Sulerzhitsky, Tatiana V Kuznetsova, Ross D E MacPhee, Aleksei N Tikhonov, Nikolai D Ovodov, Evgeny M Ineshin, Vasily N Zenin, Sergei K Vasiliev, and Fedor A Romanenko. We are also grateful to Dr Susan G Keates for grammar polishing and useful suggestions. We are grateful to anonymous reviewer for helpful suggestions and remarks. This study was supported by grants from Russian RFFI (00-06-80410, 03-06-80289 and 03-05-64434).

\section{REFERENCES}

Arslanov KA, Svezhentsev YS. 1993. An improved method for radiocarbon dating fossil bones. Radiocarbon 35(3):387-91.

Averianov AO, Vartanyan SL, Garutt VE. 1993. Melky mamont, Mammuthus primigenius vrangeliensis (Garutt, Averianov et Vartanyan, 1993) s ostrova Vrangelya (Severo-Vostochnaya Sibir) [The small size mammoth, Mammuthus primigenius vrangeliensis (Garutt, Averianov et Vartanyan, 1993), from the Wrangel Island (Northeastern Siberia)]. In: Baryshnikov GF, editor. Issledovaniya po pleistotsenovym $i$ sovremennym mlekopitayushchim. St. Petersburg: Zoologichesky Institut RAN. p 184-99.

Garutt NV, Boeskorov GG. 2001. Sherstistye nosorogi: k istorii roda [Woolly rhinoceros: to the history of genus]. In: Rozanov AY, editor. Mamont i ego okruzhenie: 200 let izucheniya. Moscow: GEOS. p 157-67.

Guthrie RD. 2003. Rapid body size decline in Alaskan Pleistocene horses before extinction. Nature 426(6963):169-71.

Heintz AE. 1966. New radiocarbon $\left({ }^{14} \mathrm{C}\right)$ age determinations from the permafrost in Siberia. Norsk Geologisk Tidsskrift 46(2):215-7.

Heintz AE, Garutt VE. 1964. Opredelenie absolutnogo vozrasta iskopaemykh ostatkov mamonta i sherstistogo nosoroga iz vechnoi merzloty Sibiri pri pomoshchi radioaktivnogo ugleroda ${ }^{14} \mathrm{C}$ [The age determination of the fossil remains of mammoth and woolly 
rhinoceros from the permafrost of Siberia with the help of radioactive carbon ${ }^{14} \mathrm{C}$ ]. Doklady Akademii Nauk SSSR 154(6):1367-70.

Heintz AE, Garutt VE. 1965. Determination of the fossil remains of mammoth and woolly rhinoceros from the permafrost in Siberia with the help of radiocarbon $\left({ }^{14} \mathrm{C}\right)$. Norsk Geologisk Tidsskrift 45(2):74-9.

Kahlke R-D. 1998. The History of the Origin, Distribution and Dispersal of the Late Pleistocene Mammuthus-coelodonta Faunal Complex in Eurasia (Large Mammals). Hot Springs, South Dakota: Fenske Company. 219 p.

Kuzmin YV, Baryshnikov GF, Jull AJT, O’Malley JM, Orlova LA, van der Plicht J. 2001. Radiocarbon chronology of the Pleistocene fauna from Geographic Society Cave, Primorye (Russian Far East). Current Research in the Pleistocene 18:106-8.

Kuzmin YV, Orlova LA. 1998. Radiocarbon chronology of the Siberian Paleolithic. Journal of World Prehistory $12(1): 1-53$.

Kuzmin YV, Orlova LA, Zolnikov ID. 2003. The dynamics of mammoth (Mammuthus primigenius Blum.) population in Northern Asia: radiocarbon evidence. In: Reumer JWF, de Vos J, Mol D, editors. Advances in Mammoth Research. DEINSEA (Annual of the Natural History Museum Rotterdam) 9:221-37.

Kuznetsova TV, Sulerzhitsky LD, Siegert C. 2001. New data on the "mammoth" fauna of the Laptev shelf land (East Siberian Arctic). In: Cavaretta G, Giola P, Mussi M, Palombo MR, editors. The World of Elephants. Rome: Consiglio Nazionale delle Ricerche. p 289-92.

Latypova EK, Yakheemovich BL. 1993. Geochronology of the Pleistocene and Holocene in the Fore-Urals. Radiocarbon 35(3):441-8.

Lõugas L, Ukkonen P, Jungner H. 2002. Dating the extinction of European mammoths: new evidence from Estonia. Quaternary Science Reviews 21(6):1347-54.

MacPhee RDE, Tikhonov AN, Mol D, de Marliave C, van der Plicht J, Greenwood AD, Fleming C, Agenbroad L. 2002. Radiocarbon chronologies and extinction dynamics of the Late Quaternary mammalian megafauna of the Taymyr Peninsula, Russian Federation. Journal of Archaeological Science 29(10):101742.

Markova AK, Smirnov NG, Kozharinov AV, Kazantseva NE, Simakova AN, Kitaev LM. 1995. Late Pleistocene distribution and diversity of mammals in Northern Eurasia (PALEOFAUNA Database). Paleontologia i Evolucio 28-29:5-143.

Orlova LA, Kuzmin YV, Zolnikov ID. 2000. Time-space systematics for mammoth (Mammuthus primigenius Blum.) and prehistoric humans in Siberia (on the basis of radiocarbon dating). Archaeology, Ethnology, and
Anthropology of Eurasia 1(3):31-41.

Schirrrmeister L, Siegert C, Kuznetsova T, Kuzmina S, Andreev A, Kienast F, Meyer H, Bobrov A. 2002. Paleoenvironmental and paleoclimatic records from permafrost deposits in the arctic region of Northern Siberia. Quaternary International 89:97-118.

Stuart AJ. 1991. Mammalian extinctions in the Late Pleistocene of Northern Eurasia and North America. Biological Reviews of the Cambridge Philosophical Society 66(4):453-562.

Stuart AJ, Sulerzhitsky LD, Orlova LA, Kuzmin YV, Lister AM. 2002. The latest woolly mammoths (Mammuthus primigenius Blumenbach) in Europe and Asia: a review of the current evidence. Quaternary Science Reviews 21(7):1559-69.

Sulerzhitsky LD. 1997. Cherty radiouglerodnoi khronologii mamontov Sibiri i severa Vostochnoi Evropy (kak substrata dlya rasseleniya cheloveka) [The features of radiocarbon chronology of mammoths in $\mathrm{Si}$ beria and northern Eastern Europe (as substratum for human dispersal)]. In: Velichko AA, Soffer O, editors. Chelovek zaselyaet planetu Zemlya. Moscow: Institut Geografii RAN. p 184-202.

Sulerzhitsky LD, Romanenko FA. 1999. The "twilight" of the mammoth fauna in the Asiatic Arctic. Ambio 28(3):251-5.

Vangengeim EA. 1977. Paleontologicheskoe obosnovanie stratigrafii antropogena Severnoi Azii (po mlekopitayushchim) [Paleontological justification of the Anthropogene stratigraphy of the Northern Asia (according to mammals)]. Moscow: Nauka Publishers. $172 \mathrm{p}$.

Vartanyan SL, Arslanov KA, Tertychnaya TV, Chernov SV. 1995. Radiocarbon evidence for mammoths on Wrangel Island, Arctic Ocean until 2,000 BC. Radiocarbon 37(1):1-6.

Vasil'chuk Y, Punning J-M, Vasil'chuk A. 1997. Radiocarbon ages of mammoths in Northern Eurasia: implications for population development and Late Quaternary environment. Radiocarbon 39(1):1-18.

Vasil'chuk YK, Vasil'chuk AC, Long A, Jull AJT, Donahue DJ. 2000. AMS dating mammoth bones: comparison with conventional dating. Radiocarbon 42(2):281-4.

Vasil'ev SA, Kuzmin YV, Orlova LA, Dementiev VN. 2002. Radiocarbon-based chronology of the Paleolithic in Siberia and its relevance to the peopling of the New World. Radiocarbon 44(2):503-30.

Vereshchagin NK, Baryshnikov GF. 1984. Quaternary mammalian extinctions in Northern Eurasia. In: Martin PS, Klein, RG, editors. Quaternary extinctions: a prehistoric revolution. Tucson, Arizona: University of Arizona Press. p 483-516. 
Table $1{ }^{14} \mathrm{C}$ dates for Late Glacial and Holocene (about 12,000-3700 BP) woolly mammoth in Siberia (after Sulerzhitsky 1997; Sulerzhitsky and Romanenko 1999; Vasil'chuk et al. 1997; MacPhee et al. 2002; Kuzmin et al. 2003) (*,**,*** = dates were run on the same sample).

\begin{tabular}{|c|c|c|c|c|c|c|}
\hline $\mathrm{Nr}$ & $\begin{array}{l}\text { Site name, } \\
\text { location }\end{array}$ & $\begin{array}{l}\text { Latitude, } \\
\mathrm{N}\end{array}$ & $\begin{array}{l}\text { Longitude, } \\
\text { E }\end{array}$ & $\begin{array}{l}{ }^{14} \mathrm{C} \text { date, } \\
\mathrm{BP}\end{array}$ & $\begin{array}{l}\text { Sigma } \\
( \pm \sigma)\end{array}$ & $\begin{array}{l}\text { Lab code } \\
\text { and } \mathrm{nr}\end{array}$ \\
\hline 1 & Wrangel Island & 71.00 & 179.00 & 3685 & 60 & Ua-13366 \\
\hline 2 & Wrangel Island & 71.00 & 179.00 & 3730 & 40 & LU-2741 \\
\hline 3 & Wrangel Island & 71.00 & 179.00 & 3920 & 30 & GIN-6980 \\
\hline 4 & Wrangel Island & 71.00 & 179.00 & 4010 & 50 & LU-2798 \\
\hline 5 & Wrangel Island & 71.00 & 179.00 & 4040 & 30 & LU-2808 \\
\hline 6 & Wrangel Island & 71.00 & 179.00 & 4370 & 70 & GIN-8249 \\
\hline 7 & Wrangel Island & 71.00 & 179.00 & 4400 & 40 & LU-2756 \\
\hline 8 & Wrangel Island & 71.00 & 179.00 & 4410 & 50 & LU-2768 \\
\hline 9 & Wrangel Island & 71.00 & 179.00 & 4740 & 40 & LU-2556 \\
\hline 10 & Wrangel Island & 71.00 & 179.00 & 4900 & 40 & LU-2740 \\
\hline 11 & Wrangel Island & 71.00 & 179.00 & 5110 & 40 & LU-2794 \\
\hline 12 & Wrangel Island & 71.00 & 179.00 & 5200 & 30 & LU-2745 \\
\hline 13 & Wrangel Island & 71.00 & 179.00 & 5250 & 40 & LU-2744 \\
\hline 14 & Wrangel Island & 71.00 & 179.00 & 5310 & 90 & LU-2742 \\
\hline 15 & Wrangel Island & 71.00 & 179.00 & 5480 & 50 & LU-2535 \\
\hline 16 & Wrangel Island* & 71.00 & 179.00 & 6260 & 50 & LU-2799 \\
\hline 17 & Wrangel Island* & 71.00 & 179.00 & 6360 & 60 & AA-11529 \\
\hline 18 & Wrangel Island & 71.00 & 179.00 & 6610 & 50 & LU-2558 \\
\hline 19 & Wrangel Island** & 71.00 & 179.00 & 6750 & 30 & GIN-6990 \\
\hline 20 & Wrangel Island** & 71.00 & 179.00 & 6760 & 50 & LU-2736 \\
\hline 21 & Wrangel Island & 71.00 & 179.00 & 6890 & 50 & LU-2810 \\
\hline 22 & Wrangel Island & 71.00 & 179.00 & 7040 & 60 & LU-2746 \\
\hline 23 & Wrangel Island*** & 71.00 & 179.00 & 7250 & 60 & LU-2809 \\
\hline 24 & Wrangel Island $* * *$ & 71.00 & 179.00 & 7295 & 95 & AA- 11530 \\
\hline 25 & Wrangel Island & 71.00 & 179.00 & 7360 & 50 & LU-2559 \\
\hline 26 & Wrangel Island & 71.00 & 179.00 & 7710 & 40 & GIN-6995 \\
\hline 27 & Nizhnaya Taymyra River & 75.25 & 99.73 & 9670 & 60 & GIN-1828 \\
\hline 28 & Pronchischev Coast & 76.75 & 110.50 & 9780 & 40 & GIN-8256 \\
\hline 29 & Nizhnaya Taymyra River & 75.25 & 99.73 & 9860 & 50 & GIN-1495 \\
\hline 30 & Bikada River & 74.92 & 106.58 & 9920 & 60 & GrA-17350 \\
\hline 31 & $\begin{array}{l}\text { Yuribey River } \\
\text { (Gydan Peninsula) }\end{array}$ & 68.92 & 71.00 & 10,000 & 70 & LU-1153 \\
\hline 32 & Nyengatiatari & 74.83 & 106.17 & 10,070 & 60 & GIN-10508 \\
\hline 33 & Engelgardt Lake & 75.10 & 110.30 & 10,100 & 100 & GIN-1489 \\
\hline 34 & Kupchiktakh Lake & 73.58 & 101.13 & 10,200 & 40 & GIN-11138a \\
\hline 35 & Lugovskoe & 61.05 & 68.57 & 10,210 & 135 & SOAN-4752 \\
\hline 36 & Goltsovaya River & 76.80 & 104.58 & 10,270 & 40 & Beta- 148640 \\
\hline 37 & Nyunkarakutari River & 75.35 & 105.50 & 10,270 & 120 & GIN-10507 \\
\hline 38 & Nizhnaya Taymyra River & 75.25 & 99.73 & 10,300 & 100 & GIN-1828k \\
\hline 39 & Mutnaya Seyakha River & 70.15 & 69.00 & 10,350 & 50 & GIN-6386 \\
\hline 40 & Berelekh & 70.55 & 149.05 & 10,370 & 70 & SOAN-327 \\
\hline 41 & Sabettayakha River & 71.15 & 71.33 & 10,420 & 130 & AA-27378 \\
\hline 42 & $\begin{array}{l}\text { Yuribei River } \\
\text { (Yamal Peninsula) }\end{array}$ & 68.92 & 69.70 & 10,460 & 120 & AA-27378 \\
\hline 43 & Nganasanskaya & 74.40 & 99.41 & 10,680 & 70 & GIN-3768 \\
\hline
\end{tabular}


Table $1{ }^{14} \mathrm{C}$ dates for Late Glacial and Holocene (about 12,000-3700 BP) woolly mammoth in Siberia (after Sulerzhitsky 1997; Sulerzhitsky and Romanenko 1999; Vasil'chuk et al. 1997; MacPhee et al. 2002; Kuzmin et al. 2003) $(*, * *, * * *=$ dates were run on the same sample). (Continued)

\begin{tabular}{|c|c|c|c|c|c|c|}
\hline $\mathrm{Nr}$ & $\begin{array}{l}\text { Site name, } \\
\text { location }\end{array}$ & $\begin{array}{l}\text { Latitude, } \\
\mathrm{N}\end{array}$ & $\begin{array}{l}\text { Longitude, } \\
\text { E }\end{array}$ & $\begin{array}{l}{ }^{14} \mathrm{C} \text { date, } \\
\mathrm{BP}\end{array}$ & $\begin{array}{l}\text { Sigma } \\
( \pm \sigma)\end{array}$ & $\begin{array}{l}\text { Lab code } \\
\text { and } n r\end{array}$ \\
\hline 44 & Krasnaya River & 74.57 & 98.50 & 10,790 & 100 & GIN-10552 \\
\hline 45 & Lugovskoe & 61.05 & 68.57 & 10,820 & 170 & SOAN-4943 \\
\hline 46 & Sosva River & 59.16 & 62.08 & 11,080 & 160 & SOAN-4842 \\
\hline 47 & Volchya Griva & 54.50 & 80.20 & 11,090 & 120 & SOAN-4921 \\
\hline 48 & Taymyr Lake & 74.05 & 93.10 & 11,140 & 180 & GIN-3067 \\
\hline 49 & Lugovskoe & 61.05 & 68.57 & 11,310 & 380 & SOAN-4755 \\
\hline 50 & Mamont River & 75.15 & 96.00 & 11,450 & 250 & $\mathrm{~T}-297$ \\
\hline 51 & $\begin{array}{l}\text { Oktyabrskoi } \\
\text { Revolutsii Island }\end{array}$ & 78.82 & 97.67 & 11,500 & 60 & LU-610 \\
\hline 52 & Lugovskoe & 61.05 & 68.57 & 11,840 & 95 & SOAN-4753 \\
\hline 53 & Arilakh Lake & 74.42 & 107.58 & 11,940 & 40 & Beta-148663 \\
\hline 54 & Konzhul & 55.33 & 92.47 & 11,980 & 155 & SOAN-4953 \\
\hline 55 & Berelekh & 70.55 & 149.05 & 12,000 & 130 & LU-149 \\
\hline 56 & Wrangel Island & 71.00 & 179.00 & 12,010 & 110 & LU-2823 \\
\hline
\end{tabular}

Table $2{ }^{14} \mathrm{C}$ dates for woolly rhinoceros in Siberia (after Heintz and Garutt 1965; Latypova and Yakheemovich 1993; Kuzmin and Orlova 1998; Sulerzhitsky and Romanenko 1999; Garutt and Boeskorov 2001).

\begin{tabular}{rllrlll}
\hline $\mathrm{Nr}$ & $\begin{array}{l}\text { Site name, } \\
\text { location }\end{array}$ & $\begin{array}{l}\text { Latitude, } \\
\mathrm{N}\end{array}$ & $\begin{array}{l}\text { Longitude, } \\
\mathrm{E}\end{array}$ & $\begin{array}{l}{ }^{14} \mathrm{C} \text { date, } \\
\mathrm{BP}\end{array}$ & $\begin{array}{l}\text { Sigma } \\
( \pm \sigma)\end{array}$ & $\begin{array}{l}\text { Lab code } \\
\text { and nr }\end{array}$ \\
\hline 1 & Lugovskoe & 61.05 & 68.57 & 10,770 & 250 & SOAN-4757 \\
2 & Zlatoustovka & 52.97 & 55.32 & 12,330 & 120 & BashGI-107 \\
3 & Yukagir Plateau & 67.00 & 157.17 & 14,260 & 150 & GIN-6007 \\
4 & Bolshoi Khomus- & 71.16 & 153.45 & 15,130 & 50 & GIN-6023 \\
& Yuriakh River & & & & & \\
5 & Bolshoi Khomus- & 71.16 & 153.45 & 15,130 & 90 & GIN-6024 \\
& Yuriakh River & & & & & \\
6 & Indigirka River & 69.87 & 147.58 & 15,850 & 80 & GIN-6020 \\
7 & Churapcha & 62.00 & 132.50 & 19,500 & 120 & GIN-9594 \\
8 & Zhuya River & 58.15 & 115.51 & 19,610 & 670 & SOAN-4732 \\
9 & Ikhine & 63.17 & 133.75 & 20,080 & 150 & SOAN-3185 \\
10 & Khroma River & 70.70 & 143.00 & 20,400 & 200 & GIN-6021 \\
11 & Kamchatka Peninsula & 55.50 & 159.50 & 20,800 & 200 & GIN-3400 \\
12 & Rel River & 55.38 & 109.00 & 25,880 & 350 & SOAN-829 \\
13 & Ikhine 2 & 63.17 & 133.75 & 26,030 & 200 & IM-239 \\
14 & Kozlovka & 56.35 & 90.77 & 26,620 & 240 & SOAN-3158 \\
15 & Kolyma River & 68.20 & 157.67 & 26,900 & 400 & GIN-6005 \\
16 & Maly Anui River & 68.00 & 162.17 & 27,300 & 300 & GIN-6018 \\
17 & Maly Anui River & 68.00 & 162.17 & 27,300 & 300 & GIN-3209 \\
18 & Wrangel Island & 71.00 & 179.00 & 29,800 & 340 & GIN-8259a \\
19 & Wrangel Island & 71.00 & 179.00 & $>30,000$ & - & GIN \\
20 & Lugovskoe & 61.05 & 68.57 & 30,090 & 800 & SOAN-4756 \\
21 & Bolshoi Khomus- & 71.16 & 153.45 & $>30,400$ & - & GIN-6023a \\
& Yuriakh River & & & & &
\end{tabular}


Table $2{ }^{14} \mathrm{C}$ dates for woolly rhinoceros in Siberia (after Heintz and Garutt 1965; Latypova and Yakheemovich 1993; Kuzmin and Orlova 1998; Sulerzhitsky and Romanenko 1999; Garutt and Boeskorov 2001). (Continued)

\begin{tabular}{|c|c|c|c|c|c|c|}
\hline $\mathrm{Nr}$ & $\begin{array}{l}\text { Site name, } \\
\text { location }\end{array}$ & $\begin{array}{l}\text { Latitude, } \\
\mathrm{N}\end{array}$ & $\begin{array}{l}\text { Longitude, } \\
\text { E }\end{array}$ & $\begin{array}{l}{ }^{14} \mathrm{C} \text { date, } \\
\mathrm{BP}\end{array}$ & $\begin{array}{l}\text { Sigma } \\
( \pm \sigma)\end{array}$ & $\begin{array}{l}\text { Lab code } \\
\text { and } n r\end{array}$ \\
\hline 22 & Varvarina Gora & 51.62 & 108.12 & 30,600 & 500 & SOAN-850 \\
\hline 23 & $\begin{array}{l}\text { Bolshoi Khomus- } \\
\text { Yuriakh River }\end{array}$ & 71.16 & 153.45 & 30,900 & 200 & GIN-6022 \\
\hline 24 & Emige & 70.40 & 133.00 & 31,500 & 300 & GIN-6013 \\
\hline 25 & Ozernaya Balya & 55.45 & 103.05 & 31,860 & 780 & SOAN-4251 \\
\hline 26 & Achchagy-Allaikha & 69.00 & 147.30 & $>32,000$ & - & GIN-6017 \\
\hline 27 & Khalbui River & 67.50 & 132.67 & $>33,000$ & - & $\mathrm{T}-172$ \\
\hline 28 & Irelyakh-Sien River & 66.17 & 151.67 & 33,100 & 400 & GIN-6010 \\
\hline 29 & Varvarina Gora & 51.62 & 108.12 & $>34,050$ & - & AA- 8875 \\
\hline 30 & Tolbaga & 51.25 & 109.33 & 34,860 & 2100 & SOAN-1522 \\
\hline 31 & $\begin{array}{l}\text { Bolshaya Chukochya } \\
\text { River }\end{array}$ & 69.03 & 156.00 & 37,100 & 1100 & GIN-6009 \\
\hline 32 & Elga River & 64.58 & 141.50 & $>38,000$ & - & $\mathrm{T}-173$ \\
\hline 33 & Dzhelon-Siene & 67.27 & 155.87 & 39,900 & 500 & GIN-6011 \\
\hline 34 & Yana River headwaters & 66.02 & 132.75 & 40,000 & 500 & GIN-6012 \\
\hline 35 & Bourdakh & 67.02 & 154.30 & 41,600 & 800 & GIN-6006 \\
\hline 36 & Khetechan & 67.80 & 161.67 & $>42,300$ & - & GIN-6014 \\
\hline 37 & Baltagai & 67.17 & 153.75 & $>42,300$ & - & GIN-6015 \\
\hline 38 & Tyung River & 65.08 & 120.00 & $>43,000$ & - & GIN-5926 \\
\hline 39 & $\begin{array}{l}\text { Bolshaya Chukochya } \\
\text { River }\end{array}$ & 69.03 & 156.00 & 43,700 & 1000 & GIN-6008 \\
\hline 40 & Kamchatka Peninsula & 55.83 & 159.67 & 46,700 & 1200 & GIN-3424 \\
\hline 41 & Bolshoi Anui River & 66.98 & 163.00 & $>49,000$ & - & GIN-6014 \\
\hline
\end{tabular}

Table $3{ }^{14} \mathrm{C}$ dates for bison in Siberia (after Kuzmin and Orlova 1998; Sulerzhitsky and Romanenko 1999; Schirrmeister et al. 2002; MacPhee et al. 2002).

\begin{tabular}{rllrrrl}
\hline $\mathrm{Nr}$ & $\begin{array}{l}\text { Site name, } \\
\text { location }\end{array}$ & $\begin{array}{l}\text { Latitude, } \\
\mathrm{N}\end{array}$ & $\begin{array}{l}\text { Longitude, } \\
\mathrm{E}\end{array}$ & $\begin{array}{l}{ }^{14} \mathrm{C} \text { date, } \\
\mathrm{BP}\end{array}$ & $\begin{array}{l}\text { Sigma } \\
( \pm \sigma)\end{array}$ & $\begin{array}{l}\text { Lab code } \\
\text { and nr }\end{array}$ \\
\hline 1 & Popigai River & 72.83 & 107.42 & 8860 & 40 & Beta-148623 \\
2 & Sushikha & 54.37 & 81.70 & 9320 & 95 & SOAN-4568 \\
3 & Krasnoyarsk & 56.10 & 92.90 & 11,610 & 110 & SOAN-1683 \\
4 & Keremensit River & 70.50 & 149.50 & 12,800 & 60 & GIN-4038 \\
5 & Listvenka, layer 10 & 55.95 & 92.40 & 13,200 & 110 & SOAN-5083 \\
6 & Birusa, layer 3a & 55.87 & 92.20 & 14,480 & 400 & LE-3777 \\
7 & Malta, layers 9.1-9.2 & 52.83 & 103.55 & 14,720 & 190 & GIN-8476 \\
8 & Kolyma River & 68.30 & 157.70 & 14,800 & 250 & GIN-3208a \\
9 & Kozhevnikov Bay & 73.50 & 110.00 & 16,390 & 120 & GIN-5727 \\
10 & Shlenka & 53.55 & 92.00 & 17,660 & 700 & GIN-2862a \\
11 & Ust-Mashinka 3 & 51.05 & 82.00 & 17,910 & 265 & SOAN-4570 \\
12 & Ikhine & 63.12 & 133.62 & 19,695 & 100 & SOAN-3186 \\
13 & Tesa River & 57.50 & 112.50 & 20,040 & 765 & SOAN-4419 \\
14 & Malta, layer 8 & 52.83 & 103.53 & 21,600 & 170 & GIN-8475 \\
15 & Kudelin & 55.33 & 84.50 & 23,050 & 255 & SOAN-3633
\end{tabular}


Table $3{ }^{14} \mathrm{C}$ dates for bison in Siberia (after Kuzmin and Orlova 1998; Sulerzhitsky and Romanenko 1999; Schirrmeister et al. 2002; MacPhee et al. 2002). (Continued)

\begin{tabular}{|c|c|c|c|c|c|c|}
\hline $\mathrm{Nr}$ & $\begin{array}{l}\text { Site name, } \\
\text { location }\end{array}$ & $\begin{array}{l}\text { Latitude, } \\
\mathrm{N}\end{array}$ & $\begin{array}{l}\text { Longitude, } \\
\text { E }\end{array}$ & $\begin{array}{l}{ }^{14} \mathrm{C} \text { date, } \\
\mathrm{BP}\end{array}$ & $\begin{array}{l}\text { Sigma } \\
( \pm \sigma)\end{array}$ & $\begin{array}{l}\text { Lab code } \\
\text { and } n r\end{array}$ \\
\hline 16 & Yuzhny & 55.83 & 102.83 & 23,400 & 455 & SOAN-3155 \\
\hline 17 & Western Chukotka & 69.50 & 166.00 & 23,590 & 1560 & GIN-8251 \\
\hline 18 & Tobol River & 56.00 & 66.00 & 24,600 & 300 & SOAN-3849 \\
\hline 19 & Balyshevo 3 & 57.48 & 107.77 & 25,100 & 940 & LE-3950 \\
\hline 20 & Faddeevsky Island & 75.70 & 144.20 & 26,100 & 300 & GIN-4329 \\
\hline 21 & Vacha River & 58.24 & 115.31 & 27,140 & 330 & SOAN-4734 \\
\hline 22 & Logata River & 73.20 & 98.15 & 27,600 & 400 & GIN-3814 \\
\hline 23 & Mylakchyn & 69.00 & 147.50 & 29,500 & 100 & SOAN-1007 \\
\hline 24 & Ust-Karakol & 51.38 & 84.68 & 28,700 & 850 & SOAN-2614 \\
\hline 25 & Belkovsky Island & 75.50 & 135.83 & 30,500 & 400 & GIN-8222 \\
\hline 26 & Bykovsky Peninsula & 71.28 & 129.42 & $>31,300$ & - & GIN \\
\hline 27 & Logata River & 73.30 & 98.20 & 31,800 & 500 & GIN-3825 \\
\hline 28 & Agapa River & 71.60 & 87.10 & 31,900 & 500 & GIN-3241 \\
\hline 29 & Vacha River & 58.24 & 115.31 & 32,170 & 250 & SOAN-4733 \\
\hline 30 & Faddeevsky Island & 75.60 & 144.05 & 32,200 & 600 & GIN-8228 \\
\hline 31 & Logovo Gieny Cave & 51.25 & 83.05 & 32,700 & 2800 & SOAN-110 \\
\hline 32 & Bykovsky Peninsula & 71.28 & 129.42 & 32,800 & 400 & GIN \\
\hline 33 & Bolshoi Kuduskit & 58.33 & 115.50 & $>33,000$ & - & GIN-8877 \\
\hline 34 & Vacha River & 58.50 & 115.00 & $>33,000$ & - & GIN-9069 \\
\hline 35 & Faddeevsky Island & 75.65 & 144.05 & 33,100 & 320 & GIN-8231 \\
\hline 36 & Logata River & 73.50 & 98.00 & 33,750 & 1200 & GIN-3824 \\
\hline 37 & Lopatka Peninsula & 72.00 & 149.67 & 33,800 & 1200 & GIN-8235 \\
\hline 38 & Duvanny Yar & 68.45 & 150.45 & 34,700 & 400 & GIN-8235 \\
\hline 39 & Maly Anui River & 68.20 & 162.17 & $>35,300$ & - & GIN-7308 \\
\hline 40 & Varvarina Gora, layer 3 & 51.63 & 108.17 & $>35,300$ & - & AA-8993 \\
\hline 41 & Bederbo-Tarida & 73.16 & 102.20 & 35,800 & 800 & GIN-3100/1 \\
\hline 42 & Olenek River & 70.55 & 122.10 & 36,800 & 500 & GIN-6097 \\
\hline 43 & Kolyma River & 68.00 & 156.00 & 37,100 & 500 & GIN-3207 \\
\hline 44 & Kolyma River & 68.50 & 156.00 & 38,400 & 800 & GIN-5711 \\
\hline 45 & Western Chukotka & 69.20 & 165.50 & $>39,000$ & - & GIN-8239 \\
\hline 46 & Bolshaya Balakhnya River & 73.60 & 100.50 & 39,200 & 800 & GIN-2764a \\
\hline 47 & Bykovsky Peninsula & 71.28 & 129.42 & 39,200 & 900 & GIN \\
\hline 48 & Sabler Cape (Lake Taymyr) & 74.53 & 100.50 & 39,760 & 870 & Beta-148624 \\
\hline 49 & Proskuryakov Grotto & 54.45 & 89.47 & 40,595 & 875 & SOAN-1518 \\
\hline 50 & Proskuryakov Grotto & 54.45 & 89.47 & 40,690 & 1150 & SOAN-1517 \\
\hline 51 & Proskuryakov Grotto & 54.45 & 89.47 & 40,770 & 1075 & SOAN-1519 \\
\hline 52 & Malta & 52.83 & 103.53 & 41,100 & 1500 & GIN-7707 \\
\hline 53 & Olenek River & 70.55 & 122.10 & 41,300 & 800 & GIN-6098 \\
\hline 54 & Olenek River & 72.45 & 123.20 & 41,700 & 1500 & GIN-6428 \\
\hline 55 & Kolyma River & 68.75 & 156.20 & 42,800 & 700 & GIN-5710 \\
\hline 56 & Kotelny Island & 75.20 & 141.00 & 43,400 & 2200 & GIN-8253 \\
\hline 57 & Birusa River & 55.55 & 97.90 & $>45,000$ & - & SOAN-3157 \\
\hline 58 & Duvanny Yar & 68.45 & 150.45 & 45,400 & 1200 & GIN-3860 \\
\hline 59 & Talalakh Lake & 73.07 & 106.83 & 45,320 & 1740 & Beta- 148625 \\
\hline
\end{tabular}


Table $4{ }^{14} \mathrm{C}$ dates for horse in Siberia (after Sulerzhitsky and Romanenko 1999; Kuznetsova et al. 2001; Schirrmeister et al. 2002; MacPhee et al. 2002).

\begin{tabular}{|c|c|c|c|c|c|c|}
\hline $\mathrm{Nr}$ & $\begin{array}{l}\text { Site name, } \\
\text { location }\end{array}$ & $\begin{array}{l}\text { Latitude, } \\
\mathrm{N}\end{array}$ & $\begin{array}{l}\text { Longitude, } \\
\text { E }\end{array}$ & $\begin{array}{l}{ }^{14} \mathrm{C} \text { date, } \\
\mathrm{BP}\end{array}$ & $\begin{array}{l}\text { Sigma } \\
( \pm \sigma)\end{array}$ & $\begin{array}{l}\text { Lab code } \\
\text { and } n r\end{array}$ \\
\hline 1 & Bolshaya Balakhnya River & 73.65 & 100.48 & 2150 & 200 & GIN-2744 \\
\hline 2 & Bolshoi Lyakhovsky Island & 73.63 & 143.10 & 2200 & 50 & GIN \\
\hline 3 & Agapa River & 71.62 & 87.00 & 3250 & 60 & GIN-3243 \\
\hline 4 & Bykovsky Peninsula & 71.28 & 129.42 & 4160 & 40 & GIN \\
\hline 5 & Nyunkarakutari River & 75.30 & 105.75 & 9010 & 140 & GIN-10509 \\
\hline 6 & Olenek River & 72.50 & 122.00 & 11,660 & 450 & GIN-6427 \\
\hline 7 & Logata River & 73.10 & 98.00 & 14,100 & 160 & GIN-3823a \\
\hline 8 & Olenek River & 70.50 & 122.00 & 14,560 & 250 & GIN-6096 \\
\hline 9 & Omolon River mouth & 68.67 & 158.50 & 15,300 & 60 & GIN-5371 \\
\hline 10 & Bykovsky Peninsula & 71.28 & 129.42 & 16,380 & 120 & GIN \\
\hline 11 & Bolshaya Balakhnya River & 73.53 & 100.49 & 17,000 & 150 & GIN-11133 \\
\hline 12 & Taymyr Lake & 74.66 & 103.00 & 17,950 & 60 & Beta-148659 \\
\hline 13 & Arilakh Lake & 74.43 & 107.58 & 18,090 & 80 & GrA-17351 \\
\hline 14 & Bolshaya Balakhnya River & 73.55 & 100.45 & 18,300 & 200 & GIN-3140b \\
\hline 15 & Kotelny Island & 75.00 & 141.00 & 19,100 & 120 & GIN-8252 \\
\hline 16 & Duvanny Yar & 68.45 & 150.45 & 19,480 & 100 & GIN-3868 \\
\hline 17 & Sabler Cape (Taymyr Lake) & 74.53 & 100.50 & 20,700 & 500 & GIN-3241a \\
\hline 18 & Bederbo-Tarida River & 73.06 & 102.16 & 21,500 & 200 & GIN-2744 \\
\hline 19 & Bykovsky Peninsula & 71.28 & 129.42 & 23,850 & 700 & GIN \\
\hline 20 & Bolshaya Balakhnya River & 73.54 & 100.50 & 23,900 & 400 & GIN-11132 \\
\hline 21 & Olenek River & 70.50 & 122.00 & 24,000 & 400 & GIN-6426 \\
\hline 22 & Sabler Cape & 74.53 & 100.50 & 24,690 & 110 & Beta-148660 \\
\hline 23 & Engelgardt Lake & 75.10 & 110.30 & 25,200 & 200 & GIN-1817a \\
\hline 24 & Sabler Cape & 74.53 & 100.50 & 26,400 & 300 & GIN-2142b \\
\hline 25 & Shchuchya River & 67.40 & 67.90 & 27,360 & 170 & GIN-6448a \\
\hline 26 & Bykovsky Peninsula & 71.28 & 129.42 & 27,500 & 400 & GIN \\
\hline 27 & Sabler Cape & 74.53 & 100.50 & 27,900 & 300 & GIN-3841b \\
\hline 28 & Anabar-Olenek watershed & 72.00 & 117.00 & 28,180 & 270 & GIN-8219 \\
\hline 29 & Kozhevnikov Bay & 73.50 & 110.00 & 28,300 & 400 & GIN-5732 \\
\hline 30 & Bykovsky Peninsula & 71.28 & 129.42 & 28,400 & 300 & GIN \\
\hline 31 & Bykovsky Peninsula & 71.28 & 129.42 & 29,000 & 450 & GIN \\
\hline 32 & Bykovsky Peninsula & 71.28 & 129.42 & 29,000 & 900 & GIN \\
\hline 33 & Faddeevsky Island & 75.50 & 144.00 & 29,100 & 400 & GIN-4330 \\
\hline 34 & Sabler Cape & 74.53 & 100.50 & 29,700 & 700 & GIN-3141a \\
\hline 35 & Pavel-Saiyngi-Yuriakh River & 41.00 & 119.00 & 29,800 & 1200 & GIN-5047 \\
\hline 36 & Kupchiktakh Lake & 73.61 & 101.15 & $>30,000$ & - & GIN \\
\hline 37 & Bykovsky Peninsula & 71.28 & 129.42 & 31,100 & 400 & GIN \\
\hline 38 & Bykovsky Peninsula & 71.28 & 129.42 & $>31,300$ & - & GIN \\
\hline 39 & Sabler Cape & 74.53 & 100.50 & 32,000 & 1000 & GIN-3141c \\
\hline 40 & Bykovsky Peninsula & 71.28 & 129.42 & 32,000 & 1000 & GIN \\
\hline 41 & Bykovsky Peninsula & 71.28 & 129.42 & 33,000 & 400 & GIN \\
\hline 42 & Bykovsky Peninsula & 71.28 & 129.42 & 34,000 & 400 & GIN \\
\hline 43 & Bykovsky Peninsula & 71.28 & 129.42 & 34,800 & 700 & GIN \\
\hline 44 & Bykovsky Peninsula & 71.28 & 129.42 & $>34,600$ & - & GIN \\
\hline 45 & Bykovsky Peninsula & 71.28 & 129.42 & 35,800 & 500 & GIN \\
\hline 46 & Bykovsky Peninsula & 71.28 & 129.42 & $>35,800$ & - & GIN \\
\hline 47 & Anabar-Olenek watershed & 72.30 & 117.50 & 36,300 & 640 & GIN-8221 \\
\hline
\end{tabular}


Table $4{ }^{14} \mathrm{C}$ dates for horse in Siberia (after Sulerzhitsky and Romanenko 1999; Kuznetsova et al. 2001; Schirrmeister et al. 2002; MacPhee et al. 2002). (Continued)

\begin{tabular}{lllllrl}
\hline Site name, & $\begin{array}{l}\text { Latitude, } \\
\mathrm{Nr}\end{array}$ & $\mathrm{N}$ & $\mathrm{l}$ Longitude, & $\begin{array}{l}{ }^{14} \mathrm{C} \text { date, } \\
\mathrm{BP}\end{array}$ & $\begin{array}{l}\text { Sigma } \\
( \pm \sigma)\end{array}$ & $\begin{array}{l}\text { Lab code } \\
\text { and nr }\end{array}$ \\
\hline 48 & Bolshaya Balakhnya River & 75.30 & 105.00 & 36,300 & 900 & GIN-3119 \\
49 & Bykovsky Peninsula & 71.28 & 129.42 & 35,900 & 600 & GIN \\
50 & Talalakh Lake & 73.07 & 106.83 & 36,770 & 610 & Beta-148622 \\
51 & Olenek River & 72.40 & 123.00 & 38,100 & 800 & GIN-6430 \\
52 & Kular Ridge & 69.83 & 133.50 & 38,700 & 1000 & GIN-4965 \\
53 & Anabar-Olenek watershed & 73.50 & 116.00 & 39,600 & 500 & GIN-3519 \\
54 & Western Yamal Peninsula & 72.00 & 68.67 & $>40,000$ & - & GIN-8544 \\
55 & Logata River & 73.20 & 98.15 & 40,200 & 1200 & GIN-3823 \\
\hline
\end{tabular}

Table $5{ }^{14} \mathrm{C}$ dates for muskox in Siberia (after Sulerzhitsky and Romanenko 1999; Kuznetsova et al. 2001; Schirrmeister et al. 2002; MacPhee et al. 2002).

\begin{tabular}{|c|c|c|c|c|c|c|}
\hline $\mathrm{Nr}$ & $\begin{array}{l}\text { Site name, } \\
\text { location }\end{array}$ & $\begin{array}{l}\text { Latitude, } \\
\mathrm{N}\end{array}$ & $\begin{array}{l}\text { Longitude, } \\
\text { E }\end{array}$ & $\begin{array}{l}{ }^{14} \mathrm{C} \text { date, } \\
\mathrm{BP}\end{array}$ & $\begin{array}{l}\text { Sigma } \\
( \pm \sigma)\end{array}$ & $\begin{array}{l}\text { Lab code } \\
\text { and nr }\end{array}$ \\
\hline 1 & Logata River & 73.12 & 98.03 & 2700 & 70 & GIN-3803 \\
\hline 2 & Pronchishchev Bay & 75.73 & 112.83 & 2900 & 60 & GIN-10529 \\
\hline 3 & Cheluskin Cape & 77.72 & 104.25 & 2920 & 50 & GIN-2945 \\
\hline 4 & Bykovsky Peninsula & 71.28 & 129.42 & 3180 & 100 & GIN \\
\hline 5 & Bykovsky Peninsula & 71.28 & 129.42 & 3200 & 80 & GIN \\
\hline 6 & Kotelny Island & 75.50 & 139.00 & 10,750 & 90 & LU-1666 \\
\hline 7 & Bolshaya Balakhnya River & 74.00 & 100.40 & 12,150 & 40 & GIN-3131 \\
\hline 8 & Wrangel Island & 71.08 & 179.50 & 15,250 & 60 & GIN-8248 \\
\hline 9 & Sabler Cape (Lake Taymyr) & 74.53 & 100.50 & 15,800 & 50 & Beta-148653 \\
\hline 10 & Agapa River & 71.70 & 87.00 & 16,080 & 100 & GIN-3239 \\
\hline 11 & Nizhniya Taymyra River & 75.30 & 99.70 & 17,800 & 300 & GIN-1815 \\
\hline 12 & Sabler Cape & 74.53 & 100.50 & 17,800 & 160 & GIN-3140c \\
\hline 13 & South of Sabler Cape & 74.50 & 100.40 & 18,370 & 70 & Beta-148628 \\
\hline 14 & Sabler Cape & 74.53 & 100.50 & 19,310 & 80 & Beta-148627 \\
\hline 15 & Bolshaya Balakhnya River & 75.30 & 105.00 & 19,710 & 70 & Beta-148654 \\
\hline 16 & Taymyr Lake & 74.42 & 100.17 & 20,770 & 180 & GrA-17500 \\
\hline 17 & Yalutarida River & 74.42 & 102.83 & 21,190 & 90 & Beta-148629 \\
\hline 18 & Khatanga & 71.97 & 102.42 & 21,330 & 70 & Beta-148658 \\
\hline 19 & Popigai River ${ }^{\mathrm{a}}$ & 72.83 & 107.42 & 21,500 & 100 & Beta-148655 \\
\hline 20 & Popigai River ${ }^{\mathrm{a}}$ & 72.83 & 107.42 & 22,530 & 220 & GrA-17605 \\
\hline 21 & Taymyr Lake & 74.42 & 100.17 & 22,370 & 80 & Beta-156194 \\
\hline 22 & Taymyr Lake & 74.42 & 100.17 & 22,610 & 100 & Beta-148652 \\
\hline 23 & Nizhniya Taymyra River & 75.45 & 99.50 & 24,660 & 110 & Beta-148657 \\
\hline 24 & Bykovsky Peninsula & 71.28 & 129.42 & $>27,000$ & - & GIN \\
\hline 25 & Bolshaya Balakhnya River & 73.60 & 100.50 & 27,440 & 150 & Beta- 148656 \\
\hline 26 & Bolshaya Balakhnya River & 73.60 & 100.50 & 32,540 & 150 & GrA-17349 \\
\hline 27 & Bikada River & 74.80 & 106.50 & 36,700 & 700 & UtC-10156 \\
\hline 28 & Bolshaya Balakhnya River & 73.60 & 100.50 & $>39,000$ & - & GIN-11130 \\
\hline 29 & Sabler Cape & 74.53 & 100.50 & 42,680 & 1240 & Beta-148626 \\
\hline
\end{tabular}

${ }^{a}$ Dates were run on same sample 